fer). To use it, when you have logged onto your university's computer system, type ftp ftp.acns.nwu.edu.; when asked for your user name, type the word anonymous; when asked for your password, type in your e-mail address. Next you will need to go into the law-and-politics directory by typing "cd law-and-politics" (all lower case, omitting the quotation marks). Use the dir command to get a listing of all the available papers. To transfer one to your site, simply type "get" and the name of the paper (again omitting the quotation marks).

The second way to access the papers is log onto your university's computer system and type "gopher gopher.nwu.edu" (all lower case, omitting the quotation marks) or just type gopher and then find the Northwestern University gopher by selecting the appropriate menu items. You will see a menu of choices; select the appropriate one. Gopher allows you to view the papers before transferring them to your site. The surest way to transfer them is to issue a save command and the paper will be saved on your space at the computer you are logged onto.

Please address inquiries to Herbert Jacob, Department of Political Science, Northwestern University, 601 University Place, Evanston, IL 60208 (e-mail: mzltov@nwu.edu; voice mail: (708) 491-2648); or Michael Brintnall at APSA (e-mail: incem024@SIVM; (202) 483-2512).

\section{Jones Appoints Paul Allen Beck 1994 Program Chair}

APSA President-Elect Charles O. Jones, University of WisconsinMadison, has appointed Paul Allen Beck, The Ohio State University, to be the 1994 program chair. The 1994 annual meeting will be held September 1-4 in New York City.

The 1994 Program will continue the practice of the past three years of integrating the organized sections with the program committee sections. This year, however, the program "sections" will be referred to as "divisions." Under a Council "rule of three" policy, each organized sec- tion was asked to nominate three candidates to be section head for that organized section's field. The program chair then selected one of the three nominees to serve on the 1994 program. Additionally, Beck selected other members of the program committee to handle parts of the program not covered by the organized sections. The APSA Council subsequently approved all appointments to the 1994 program committee.

\section{Call for Papers: 1994 Annual Meeting}

The 1994 Program Committee is ready to receive paper proposals and offers to appear as discussants or panel chairs for the APSA Annual Meeting in New York from September 1-4, 1994. The deadline for the receipt of submissions is December 1 . Proposals for whole panels or roundtables are also welcome, especially those that incorporate the program theme or focus on either important works (recent or classics) or the contributions of leading scholars. It is imperative that such proposals for panels or roundtables be submitted well before the December 1 deadline.

Please send your proposals or offers to serve as chairs/discussants directly to the member of the Program Committee, listed below, whose program division (formerly called sections) is most appropriate. If you are applying to more than one division of the program, either because each appears suitable for what you have in mind or because you are submitting different proposals, you must inform each division head of the other divisions to which you have applied. More general inquiries or suggestions may be addressed to the Program Chair or to Jennifer Hacha Richards, Convention Manager, APSA, 1527 New Hampshire Avenue, NW, Washington, DC 20036.

Proposals for papers should include complete information on all authors (full name and affiliation as they are to be listed in the program, address, phone and fax numbers, and e-mail address, where relevant), a title, and a synopsis or abstract. Proposals for panels or roundtables should contain a title and abstract describing the theme as well as complete information on each of the participants. Offers to serve as a discussant or panel chair should be accompanied by a description of areas of specialization or a short c.v.

Prospective participants should be aware of two APSA Council policies governing participation at annual meetings:

\section{Acceptance of a proposal by the} Program Committee obligates you to preregister (and pay the registration fee) prior to June 1 , 1994. If you fail to preregister, you will not be listed in the official program.

2. Participants may appear on two (but no more than two) panels in any capacity-chairing a panel or roundtable, acting as a discussant, or presenting a paper.

In order to minimize the problems created by late papers and "no shows" among panelists, every effort will be made to include on the program only those people who definitely plan to attend the meetings and pledge to meet the deadlines for paper submissions. These efforts will include two proposals to the APSA Council for improving compliance with the norms and rules of professional meeting participation. We will request that division heads and panel chairs be instructed to prohibit formal discussion of papers that do not reach the discussants with sufficient time for them to prepare comments. We also will propose that a list of panel "no shows" be passed along to the following year's program committee, so that a record is kept of those failing to fulfill their professional responsibilities. The intent of these new practices is not to limit participation at the APSA meetings; rather, our desire is to minimize the problems created by irresponsibility among a few panel participants and to provide participation opportunities only to those who fulfill their professional commitments.

1994 Program Theme: Politics and Political Science in a Changing World

The theme of the 1994 Annual Meetings recognizes the many impor- 
tant changes that have occurred throughout the world in recent years. The implications of these changes for politics and governance, as well as for the discipline that studies them, will provide ample material for special panels and roundtables throughout the various divisions in the 1994 program.

Recent years have witnessed sometimes breathtaking change in the domain of politics and government. The Soviet empire has disintegrated - triggering the democratic transitions in many of its former member states but internal conflict and economic collapse that threaten to stifle democratic impulses in others. Throughout the world, democracy seems to be ascendent but so too are the threats to democracy. As regular news reports from the former Yugoslavian state or India tell us, resurgent ethnic and religious strife are undermining democratic norms and practices. Even as such a traditionally closed society as China has opened up to market-driven economic forces, it has clamped down on democratic ones. Nationalism seems to be waning in Western Europe in the spirit of Maastricht and the prospect of continent-wide economic union, but it appears on the rise in other parts of the globe. With the end of the Cold War, a stable bipolar international system has given way to a "new world order" with its uncertain balance of power and heightened prospects for uncontrolled regional disorder. Economic interdependencies among nations are growing, and nations seem less able to prevent international economic forces from driving their domestic politics; yet national governments appear to receive ever more of the blame from their citizens for economic decay.

Even at home, change seems to be the dominant theme. A new administration brings the Democrats into power, and produces undivided control of government, for the first time in over a decade-dashing immediate Republican dreams of realignment. But the agenda of problems it must confront makes its fate unusually uncertain. A populistic turn to direct democracy and term limitations amidst disappointment with representative democracy, federal devolution of fiscal responsibilities upon the states and localities, the straightjacket of unprecedented national debt, smoldering racial and religious tensions, the rise of special interests, and the dramatic challenge by Ross Perot to the two-party monopoly on presidential elections have made traditional American political practices and institutions seem more fragile than before. Beyond this, perhaps driving it, Americans-like many people elsewhere-seem to be challenging the old values while forming only uncertain attachments to the new ones.

A world in change, and the foregoing are just a few of the most dramatic examples of these domestic and international transfigurations, provides political scientists with a wide array of novel-or at least "different" phenomena-to study. It shifts the locus of intellectual effort away from trying to understand stability and continuity and toward questions of disequilibrium and change. Ever mindful that theirs is a "science" dedicated to explaining current situations and events, political scientists of all persuasions are turning as they always have to face the new realities, and the discipline is being altered in their wake. Democratic transition and consolidation, political economy, and mass communications have emerged as new (or renewed) areas of focus. Students of the Cold War and the Soviet empire are turning to new foci or adopting new theoretical approaches and new tools of analysis to examine the remaining problems. Amidst the usual research reports on recurrent themes in our discipline, which rightly dominate any annual meeting, it is fitting for the 1994 annual meetings to pay special attention to how political science has dealt with-and been influenced by-this changing world.

\section{Program Committee and Its Call for Papers}

Program Chair: Paul Allen Beck, Department of Political Science, The Ohio State University, Columbus, OH 43210; 614-292-2880 (office); 614-292-1146 (fax); TS1449@OHSTMVSA (e-mail).

1. Political Thought and Philosophy: Historical Approaches: Mary Dietz,
Department of Political Science, University of Minnesota, Minneapolis, MN 55455; 612-624-0597 (office); 612-626-7599 (fax).

As historical artifacts, political theories can be understood as operating on two different levels in relation to the problem of transformation and change. At one level, each political theory in the past-including the recent past-can be understood as responding to certain specific problems of transformation in the "changing world"' of its time. At another level, the history of political thought as a whole-ancient, medieval, modern, and contemporary-can be understood as a traditional enterprise that embodies and records the phenomenon of world change and transformation. On both of these levels, then, historical approaches to political thought and philosophy instinctively respond to the theme of this year's meeting, "Politics and Political Science in a Changing World." There is wide room for a diverse array of paper and panel proposals.

Papers that explicitly deal with the problem of change-with time, transformation, development, progress, stasis, reform, or revolution-in the history of political thought are especially encouraged. Papers might address the way in which particular theorists (say, Aristotle, Machiavelli, Hegel, or Marx) conceptualized the nature of change or revolution or stability within and among states or political systems. Alternatively, papers might address specific historical periods or contexts (for example, temporal consciousness in the Italian Renaissance); concepts that themselves embody the very ideas of change and temporality (perhaps, "time," "change," "reform,", "revolution," or "progress"); or the general problem of theoretical or conceptual change in the history of political thought. Of course, papers that argue for the persistence of certain themes or perennial problems are quite appropriate.

Additionally, we might take this opportunity to assess why, how, and with what immediate consequences, some historical thinkers are enjoying a revival in the contemporary discourse of political philosophy 
(Aristotle, Hobbes, Hegel, or Nietzsche, for example), and others are apparently experiencing interment (like Plato, Kant, and Marx). Papers that exhume important figures in the history of political thought and consider their significance for current debates (perhaps Thucydides, Augustine, Machiavelli, or Burke) fit in here as well.

This year's theme also raises the issue of how theories and theorists of the past can contribute meaningfully to our understanding of contemporary problems of politics and political change. Assuming that in the present we can turn to the past as a way of reflecting upon the future, papers and panels might explicitly confront some intractable political dilemmas facing the post-Cold War world-democratization, nationalism, ethnic violence, racial conflict, the violation of human rights, and crises of legitimation-by drawing upon historical texts, thinkers and ideas in order to illuminate these (or related) issues in different ways. We should also attend to the significance that historical texts and theories might have for contemporary social movements and emancipatory struggles as women and men of different race, class, gender, and sexual identity seek to articulate conceptions of democracy, equality, liberty, justice, rights, or citizenship.

Finally, this is an appropriate forum in which political theorists might consider the changing nature of the discipline of political science itself, or of the subfield of political theory within it. I welcome proposals or panels that explore what Aristotle called "the master science of the Good" or what John Adams called "that divine science of politics" from a variety of theoretical perspectives, as well as papers that undertake the study of the history of the discipline, especially with a view toward its current status and future prospects.

These areas by no means exhaust the possibilities for paper proposals in this division. If you have suggestions for a panel or roundtable on topics or themes that go beyond this year's agenda-including perhaps on a recent influential book or authorplease send them along.

\section{Normative Political Theory:}

Jennifer Hochschild, Department of Politics, Princeton University, Princeton, NJ 08544-1012; 609-2585634 (office); 609-258-1985 (fax); HOCHSCHI@PUCC (e-mail).

In keeping with the theme of "Politics and Political Science in a Changing World," I propose that our division focus on transitions, or more informally, change. For example, proposals could focus on institutional transformation, such as the conditions necessary for movement from an authoritarian to a democratic state, or from an electionbased representative democracy to a participation-based direct democracy. Or proposals could focus on individual change, building off last year's APSA focus on the politics of identity. Thus papers on the changing meaning of "the political" or on the redefinition of problems from individual and private to collective and public would be welcome. Proposals could also focus on conceptual change, such as new interpretations of the meaning of justice or citizenship, or trajectories in the work of a single author, or the implications of looking at works in the canon through the lens of gender or racial analyses.

Also in keeping with the theme of change, I urge you to think of imaginative ways to present ideas and engage in exchanges. I welcome proposals for "'meet the author" panels, or retrospectives on the work of $\mathrm{X}$ by $\mathrm{X}$ and his or her students or successors, or roundtables that include both political practitioners and theorists reflecting on their practice.

These are examples; my main point is to urge creativity in the construction of the sessions as well as in the arguments presented during sessions.

Finally, I have a strong proclivity for work in normative theory that is grounded in or speaks to "real world" politics. That may imply combining empirical research and philosophical reflection in a single paper, or across a panel of participants. It need not, however; purely normative analyses of real political problems are obviously appropriate to this section. I will, nevertheless, give precedence to paper or panel proposals that directly engage with "the changing world," to coin a phrase.
3. Foundations of Political Theory: Edward Portis, Department of Political Science, Texas A\&M University, College Státion, TX 77843; 409-8452511 (office); 409-847-8924 (fax).

The purpose of the Foundations Section has always been to encourage innovative approaches to political theory and to critically assess the adequacy of established modes of theorizing, especially as they relate to the other fields of political science and to the discipline as a whole. All paper and panel proposals serving these ends are welcome.

Three categories of topics are particularly appropriate for Foundations panels. The first includes all papers and panels dealing with the theoretical enterprise itself: its purpose, its consequences, its methodologies, and its imperatives. The second encompasses explorations into the relevance of political theory to political science as a social scientific discipline, as well as to the other social sciences. The third category embraces the theoretical definition and evaluation of specific policy problems, as well as the assessment of proposed solutions. This category might be especially conducive to topics exploring dimensions of the theme for the 1994 meetings, "Politics and Political Science in a Changing World."

I recognize that these categories are not mutually exclusive, and it certainly is not my intent to preclude proposals that do not fit neatly into one of them. I am open to suggestions for roundtables, although I prefer that they be focused upon a contentious issue rather than upon a particular author or work.

4. Formal Political Theory: Paul Johnson, Department of Political Science, University of Kansas, 504 Blake Hall, Lawrence, KS 66045 ; 913-864-3523 (office); 913-864-5208 (fax); PAULJOHN@UKANVM (e-mail).

Proposals are invited for papers that support the use of any sort of formal model to characterize a political process and derive statements about it. The boundaries of this division are demarcated by the mathematical nature of the method of analysis, not by the substance of the research topics. Hence, proposals are 
welcome from scholars who are interested in any of the broad array of political science research topics. This certainly includes the mainstays of recent formal theory, such as collective decisionmaking, bureaucratic behavior/policy implementation, interest group politics, and international alliances and crises.

The theme "Politics and Political Science in a Changing World" ought to inspire some fruitful panels.

Ongoing constitutional changes in the world (both wholesale revision or structural "'fine-tuning') ought to tie in with formal research on constitutions, electoral systems, single vs. multimember districts, and the properties of various voting methods. The growing importance of the United Nations might motivate papers on voting in voluntary organizations. Within the United States, reform of laws on campaign finance, changes in electoral systems to foster minority representation, and congressional reform should motivate papers. Perhaps the time is ripe for formal analysis of proposals for electronic democracy that crop up from time to time.

In addition to emphasizing papers relevant to this year's theme, I hope to organize panels on recent developments in mathematical modeling. In game theory, papers using and/or evaluating the application of Bayesian/sequential equilibrium concepts are encouraged. Also, I also hope there will be papers using computer simulation models to study candidate position taking, voting or other processes too complicated for traditional analysis.

\section{Political Methodology: Walter Mebane, Department of Govern- ment, Cornell University, 101 \\ McGraw Hall, Ithaca, NY 14853- 4601; 607-255-3868 (office); 607- 255-4530 (fax); WRM1@- \\ CORNELL.EDU (e-mail).}

Political methodology tries to advance the use of empirical data to develop and test theories about government, politics, political behavior, and policy. This includes appraising how well the methods of statistics, econometrics, biometrics, and other quantitative social sciences apply to the models and data of political sci- ence. But, when necessary, we must also develop new analytical methods to solve those problems that are unique to political science research. One important challenge is to find ways to make reliable inferences even when the available data are not quantitative or not extensive, and even when existing theory does not specify a parametric model. In this all too common situation, questions of prior information, measurement, specification, and robustness are urgent. To make a useful methodological contribution it is often necessary to begin by strengthening the theory.

In view of the theme for this year's meetings, I especially invite proposals for papers, panels or roundtable discussions concerning three topics: (1) methodological challenges facing survey or other research on political change in Eastern Europe or the former Soviet Republics; (2) methodological issues in research on environmental politics or policy; (3) methodological problems confronting policymaking or political analysis in the areas of health, education, welfare, employment or trade in the United States, in other countries, or in the international arena. Technical topics of particular interest include complex survey data, Bayesian analysis using the Gibbs sampler, generalized linear models, additive models, robust estimation, misspecification, mixed models, statistical graphics, and statistical and econometric methods for nonlinear systems models. Lucid expositions of recent developments in these areas, with discussion both of their possible applications in political research and their limitations, are welcome. Exemplary analysis applying such methods is also of interest.

Proposals touching on other substantive concerns are also welcome, as is work in the technical areas traditionally of interest in political methodology. These include time series analysis, panel data analysis, experimental and quasi-experimental designs, simulation and scaling, methods for discrete data, censoring and selection problems, maximum likelihood and other approaches to estimation, ecological inference, nonparametric methods, regression diagnostics, and other topics. I also invite proposals concerning graduate or undergraduate methods instruction. Proposals to discuss professional standards and institutional arrangements for reviewing, verifying and archiving data and software used in empirical research are also of interest.

\section{Legislative Studies: Diana Evans, Department of Political Science, Trinity College, Hartford, CT 06106; 203-297-0616 (office); 203-297-2257 (fax); DIANA.EVANS@MAIL.- TRINCOLL.EDU (e-mail).}

The theme of the 1994 meetings, "Politics and Political Science in a Changing World," is particularly appropriate for legislative scholars. Proposals for panels, papers, and roundtables in all areas of legislative research, including non-American, the U.S. Congress, and state and local legislative systems are invited. The following describes my emphases but papers and panels with other approaches are also welcome.

In recent years legislatures have undergone rapid and often stunning change, especially in formerly nondemocratic regimes. I would be especially interested in proposals on the evolution and operation of such legislatures. Historically democratic states also have been affected by changes in their political, social, and economic environments, and papers that deal with the impact of such changes on those nations' legislatures are also welcome.

Second, I am interested in papers and panels on the U.S. Congress and its continuing evolution at all levels. Third, I would like to see proposals that deal with state and local legislatures, particularly those that seek to develop generalizations based on examination of more than one legislature.

Finally, I would be receptive to proposals to organize panels around a recent important and especially influential work in legislative studies or classics of continuing importance to legislative scholars.

7. Presidency Research: Paul Quirk, Department of Political Science, University of Illinois-Urbana, $702 \mathrm{~S}$. Wright Street, Urbana, IL 61801; 217-333-1356 or 217-244-4826 (office); 217-244-5712 (fax). 
In evaluating paper proposals, I will be looking for substantial research efforts that promise to deepen our understanding of the presidency. I will try to judge this promise by standard criteria of theoretical interest, strength of evidence, and quality of analysis. (That is, I will largely suppress my own interests and preferences and avoid any quirkiness in the selection.) Although I will maintain the tradition of giving some attention to the current presidency, I will not otherwise be interested in papers that represent casual, anecdotal commentary on presidential decisions or performance-a style of work that, fortunately, is no longer esteemed in the presidency subfield. For a few panels, I will be interested in papers that primarily review and criticize existing research.

To permit me to make better judgments about the quality of proposals, I will strongly favor proposals that go well beyond a title and one or two sentences of description and that provide an adequate basis for expecting a solid paper. Particularly for scholars who are younger or whose work I do not know, I will favor proposals that include a page or so of relevant information, including: the theoretical or practical issues addressed, the nature of any data, the methods of analysis, the nature of any theoretical work, the author's training or experience in such research, the work's relation to previous publications or other research (by the authors or other scholars), and the current status of the research (for example, whether the data have already been collected, whether related papers have already been completed). In the past, I have found that the cogency of these statements was the best evidence on whether a paper was likely to be good. In some cases, I will probably request additional information, or even copies of previous papers. Co-authors should indicate which author I should correspond with.

For the most part, I will form panels myself to find places for as many of the best papers as I can. Nevertheless, I welcome any suggestions for panels and would be pleased to receive a considerable number of them. I would also welcome suggestions from paper pro- posers concerning the kinds of papers they would like to be matched up with. Neither the feasibility of such suggestions from paper authors nor my own efforts to find matches, however, will be a significant factor in decisions on acceptance. To the extent that choices become necessary, I will be more interested in good papers than in coherent panels.

I will be especially interested in suggestions of panels of the following kinds: (1) panels that relate creatively to the meeting theme of "Politics and Political Science in a Changing World"; (2) panels that attempt to cast light on the current presidential administration; (3) panels that deal broadly and critically with major literature or trends in research or that point to significant new developments in the presidency subfield.

Finally, I should mention that the Presidency Research Division may be involved in some experimentation with the mechanics of distributing papers or with the practices for ensuring that panel participants meet their obligations, two areas in which problems have become increasingly apparent in recent years. The Association is discussing possible innovative strategies in both areas. Counting on students of the presidency to tolerate an exercise of shadowy "implied powers," I have volunteered the division for possible experimentation with these strategies. I will make sure that participants in the section are informed of any new procedures well in advance.

\section{Elections and Electoral Behavior: Kathleen Knight, Department of Political Science, University of Houston, Houston, TX 77204-3474; 713-743-3900 (office); 713-743-3927 (fax); POLS32UHUPVM1 (bitnet).}

Proposals for papers and panels are welcome in the broad area of elections and electoral behavior, and need not necessarily be confined to those in which the dependent variable is the vote. In keeping with the program theme I particularly encourage attention to the way models of the vote have changed in response to methodological innovations, and to changes in the broader political and economic context. I expect to have panels devoted to recent American national elections, and encourage submissions which consider aspects of American voting behavior across time. Comparative analyses of elections and electoral behavior are also welcome.

Panels in this section are also likely to focus on individual level models of voter decisionmaking, spatial and directional models, aggregate analyses, election forecasting, and micromacro linkages. Proposals are also encouraged which examine attitudinal influence on electoral behavior such as ideology, partisanship, policy preferences, and group-based or other heuristics, or which focus more broadly upon democratic values, socialization, and attitudes toward voting as a form of political participation. Other potential topics include: the management of candidate images and their evaluation by voters, the impact of independent candidates, successes of relatively recent entrants to the electoral arena (women and minorities), campaign strategies, campaign funding and proposed reforms, and the impact of broader electoral reforms such as. easing access to registration, noexcuse absentee voting, and term limits.

The enumeration of the above should not be interpreted as barring other good ideas.

\section{Public Opinion and Participation:} Stephen E. Bennett, Department of Political Science, University of Cincinnati, Mail Location \#375, Cincinnati, OH 45221-0375; 513-556-3304 (office); BENNETT@UCBEH (e-mail).

The 1994 conference's theme is opportune for students of public opinion and political participation, for "change" is the watchword in both fields. In the United States, new issues, new leaders, and new movements may be significantly altering grassroots politics. Change is even more fundamentally altering mass politics in many parts of the world.

How are political scientists dealing with rapidly shifting citizen involvement in and dispositions toward public affairs? Are theoretical frameworks and methodological approaches that scholars have utilized 
to study public opinion and political participation still fruitful, or must new models and methods be found if we wish better to comprehend citizen politics? Is it possible that concepts, theories, and methods formerly used by students of grassroots politics, but recently neglected, could again become useful scholarly tools?

Proposals are solicited for papers and panels on these and other topics dealing with changing citizen politics and the impact of these changes on the discipline. Although I anticipate many proposals focusing on the United States, I hope to receive papers and panels on public opinion and political participation in other lands.

I especially welcome proposals dealing with increased voter participation in the 1992 elections. Papers proposing new ways of conceptualizing and measuring the concept of political participation are also sought. It would be interesting to see how newer modes of citizen involvement, such as talk radio and TV shows, are altering the political process here and abroad.

Several recent studies have focused on changing and "unchanging" public opinion in America. Papers assessing whether and how recent research has altered our understanding of public opinion would be welcome. Proposals calling for new theoretical models and/or methodological approaches to studying public opinion are also solicited. In addition, papers dealing with how new methods or new data bases, such as the growing corpus of polls conducted by the Times Mirror's Center for The People \& The Press, could help scholars better understand American public opinion are welcome.

Papers or panels trying to "pour new wine into old bottles" are also sought. It is sometimes fruitful to return to models once applied to political behavior, but lately neglected, to see if they might be refurbished to shed useful light again. An example is mass society theory, which some scholars found useful a generation ago but long has been in the doldrums. Does either the old model, or a "new and improved" version, help us understand citizen politics today?
Finally, there is constancy in the midst of change. I welcome proposals exploring how a particular concept, theory, or method has stood the test of time. Proposals are requested that look at the intellectual history of a concept, theory, or methodological approach in the fields of public opinion and political participation.

\section{Political Organizations and Par-} ties: Marjorie Hershey, Department of Political Science, Indiana University, Bloomington, IN 47405; 812855-5094 (office); 812-855-2027 (fax); HERSHEY@UCS.INDIANA.EDU (e-mail).

I'd welcome research on all aspects of political parties, groups, and social movements. I would be particularly interested in research bearing on the causes and consequences of change in political organizations, including:

(1) the evolution of third parties, independent candidate organizations, and new groups; how and why groups decline and disband; research stimulated by the work of Jack Walker.

(2) the internal dynamics of parties, groups, and social movements, including efforts at intra-party or -group democracy (e.g., new looks at the impact of the Democratic party reforms) and opportunities for popular participation.

(3) changing relationships among political organizations: the impact of new groups on the political parties; the impact of independent candidate organizations on parties and groups; effects of media organizations on interest group and party behavior; and their implications for intermediation in American politics.

(4) an assessment of the study of political organizations to this point: comparative research methods, innovative methods (whether low- or high-tech) for answering important questions, how research findings on political organizations have been affected by the choice of certain research methods (e.g., questionnaires and survey research) rather than others, the relevance of classics in the field (such as Michels, Duverger, Downs, Schattschneider and others) for current problems.
Please include a brief discussion of the focus of your paper, the analytical methods used, and your assessment of the topic's significance. And please keep in mind that the earlier you submit your proposal, the better the chance that I'll be able to give it full consideration.

11. Law and Courts: Judith Baer, Department of Political Science, Texas A\&M University, College Station, TX 77843-4348; 409-845-2246 (office); 409-847-8924 (fax); E339JB@TAMVM1 (bitnet); E339JB@LEWIE.TAMU.EDU (internet).

Like the Organized Section itself, the theme of the 1994 annual meeting is inclusive if not all-encompassing. I invite potential participants to read this call for papers by analogy with the Ninth Amendment: the enumeration of certain topics should not be construed to exclude others. I anticipate a variety of paper, panel, and roundtable proposals, and will be open to the possibility of cosponsorship with other program sections.

The Democratic victory in the 1992 presidential election, and its implications for the federal judiciary, are obviously part of the "changing world" of public law. This development demands our attention, but it need not monopolize our program. I urge participants to consider the changes, dramatic or gradual, that have made the strongest impact on their own work. In what ways has that which we study changed, since we began studying it? Does the adage, "the more things change, the more they stay the same" apply to our particular interests?

I welcome efforts to analyze these changes which combine subfield specialties and/or link the past, present, and future. Doctrinal trends, interbranch and intergovernmental relations, and concepts of the judicial role offer fruitful subjects for analysis. I hope the whole will be greater than the sum of its parts; to that end, I welcome your offer to participate, whether or not my description seems to fit your interests.

12. Constitutional Law and Jurisprudence: David O'Brien, Depart- 
ment of Government and Foreign Affairs, University of Virginia, Charlottesville, VA 22901; 804-924-3358 (office); 804-979-6318 or 804-9243359 (fax).

Proposals for papers and panels in all areas of constitutional law and jurisprudence are invited. While all subjects and approaches-traditional, new, and "postmodern" - are welcome, I especially encourage submissions related to the conference theme, "Politics and Political Science in a Changing World." With that theme in mind, I am particularly interested in receiving proposals that run in the directions suggested below:

First, I hope that at least one panel or roundtable will be on research in comparative constitutional law and politics.

Second, along with analytical, historical, and doctrinal studies of the work of the Supreme Court and continuity or changes in constitutional interpretation, I encourage proposals on related developments in state constitutional law, whether in substantive areas of public policy or in relation to other institutions and policy processes in American politics.

Third, papers and panels addressing the current state of "liberal legalism," feminist jurisprudence, civic republicanism, communitarianism, or pragmatism, as well as their contributions to constitutional interpretation, are especially welcomed.

Finally, I encourage proposals that are interdisciplinary and methodologically or theoretically innovative. A panel, for example, might be devoted to reassessing the "classic" theory of free speech in light of contemporary arguments for a "New Deal First Amendment" and competing jurisprudential theories, or on the basis of empirical research on commercial mass media and the impact of new communications technology on public opinion and behavior.

As noted above, this "wish list" is suggestive, not exhaustive or exclusive. I remain open as well to cosponsoring panels with other divisions and groups. If you plan on proposing a paper or a panel, please contact me well before the deadline.

13. Public Administration: Rosemary O'Leary, Department of Public
Administration, 208 Maxwell Hall, Maxwell School of Citizenship and Public Affairs, Syracuse, NY 132441090; 315-443-5871 (office); 315443-5451 (fax); ROLEARY@SUVM (e-mail).

Paper and panel proposals on all aspects of public administration scholarship are invited. Requests to serve as discussants or chairs also are welcome. The conference theme, "Politics and Political Science in a Changing World," raises many possibilities for papers and panels including, but not limited to: Changing paradigms, comparative administration, internationalization, the changing role and image of bureaucrats, innovation, accountability, administrative behavior, motivation of public sector employees, changing views of leadership, effectiveness, legitimacy, ethics, decisionmaking, policymaking, the changing political environment of public administration, cutting-edge organization theories, alternative modes of administration and service delivery, cuttingedge methodological issues, and new perspectives in teaching public administration. This list is meant to be suggestive, not exhaustive. Any good idea is welcome. A sincere effort will be made to accommodate topics that represent the excellent scholarship and rich diversity of research on public administration carried out by our section members.

\section{Federalism and Intergovernmen-} tal Relations: Michael A. Pagano, Department of Political Science, Miami University, Oxford, $\mathrm{OH}$ 45056; 513-529-2000 (office); 513529-6939 (fax); MPAGANO@MIAMIU.ACS.MUOHIO.EDU (e-mail).

As the nature and face of federalism in the United States continues to change under a new administration and after more than a decade of regulatory federalism, surely federalism has become a dominant political concern of a changing world. The sorting out of roles and relationships among federal-state-local governments has dominated the Clinton administration's first year of office, just as it has dominated the politics of Eastern Europe, Russia, Israel, the new European Community, and elsewhere. The theme for this year's panels and roundtables is federalism's role in understanding the dynamic political processes of a changing world.

Papers and panel proposals on intergovernmental themes from the United States and around the world are welcomed. Especially encouraged are papers on comparative federalism and state-local relations in newlydemocratizing nations, empirical and theoretical studies on the emerging shape of intergovernmental relations in the United States, and analyses of cooperative and coercive federal and state policies. Further, roundtables might be considered for the following general themes (among others): mandates, health policy or infrastructure policy and the states in the future federal system; the eroding/expanding autonomy of local governments; prospects for reinvigorating the 10th Amendment; state v. federal protection of rights; financing the intergovernmental system; cities in the new intergovernmental system; "shift-and-shaft" federalism or other forms.

Paper proposals must provide a one-page abstract, detailing the topic and its significance, the methodology and data, and possible implications for understanding or improving intergovernmental relations. Proposals for panels must provide complete details on each proposed paper. For roundtables, include full information about the subject matter to be examined, as well as information about each participant.

15. Urban Politics: Dianne Pinderhughes, Department of Political Science, University of Illinois-Urbana, 702 S. Wright Street, Urbana, IL 61801-3696, 217-333-3273/7781 (office), 217-244-5712 (fax); and Heywood Sanders, Department of Urban Administration, Trinity University, 715 Stadium Drive, San Antonio, TX 78212, 210-736-7463 (office), 210-736-8106 (fax).

The world of cities and urban politics has shifted substantially over the last 20 years. Proposals for panels, roundtables, and papers are particularly invited that deal with the structural and fiscal changes that have affected cities in recent decades. We are interested in such topics as the 
changing structure of urban governance, including the rise of independent governmental entities, and the new urban fiscal politics. In addition, the change in urban populations requires the creation of new multiracial and ethnic coalitions in major urban centers. The juggling and management of group interests and demands will be the focus of one or more panels.

In the 30 years since the publication of Banfield and Wilson's City Politics, both the research field and the cities themselves have also changed. The chairs invite proposals that seek to revisit such locales as Boston, New Haven, Chicago, Oakland, and New York City in order to re-examine "classic" urban politics studies and define how the field and the cities have evolved.

16. State Politics and Policy: John McIver, Department of Political Science, University of Colorado, Boulder, CO 80309-0333; 303-4928723 (office); 303-492-0978 (fax); MCIVER@COLORADO (e-mail).

State politics is a subfield of often unrealized potential for the student of American politics. A wide variety of topics will be considered that reflect the promise of the subfield. This promise is most readily realized in the explicit comparative study of similar political systems. Comparative state research that advances theoretical arguments or tests existing theoretical conceptions of politics is welcome. Comparative state vs. national or state vs. local research that attempts to generalize political theories across levels of government is also sought. If state public policy research is to realize its potential, we may need new theories of state politics. Papers moving beyond the "one policy" study are encouraged as are those that attempt to develop general theories from the wealth of state policy case studies.

In keeping with the theme of this year's program, I encourage submission of papers and panels that examine recent changes in the American political landscape. If 1992 was an election of change, surely we should see it reflected in state politics and policy. The mandate for change claimed by President Clinton likely has visible precursors in state poli- tics. Other changes at the state level, however, may only occur in response to changes in federal policies after 12 years of Republican control of the White House.

Change of the type debated in public circles requires radical shifts with past policies. And if government will not or can not change, the electorate may have to force the issue. Abrupt changes in state politics often reflect citizen refusal to continue the business of government as usual, e.g., tax revolts, term limits. These changes forced on state governments raise a variety of question: How critical is the initiative process in state policymaking? Will this exercise of direct democracy work to the detriment of representative government? Or is direct democracy really special interest group policymaking in disguise?

To study political change systematically requires a theoretical basis for understanding when and why change occurs and with what effect. Do we have good theories of political change? Is state politics a good place to study these changes? Can the state politics literature on innovation and diffusion focus the attention of the rest of the discipline on the study of change?

Paper proposals should include a detailed abstract describing the theoretical motivations for the paper as well as the evidence to be presented. Panel proposals should offer a diversity of substantive and methodological perspectives.

17. Public Policy: Kenneth Meier, Department of Political Science, P.O. Box 413, University of Wisconsin-Milwaukee, Milwaukee, WI 53201; 414-229-4221 (office); 414229-5021 (fax); MEIER@CSD4.CSD.UWM.EDU (e-mail).

Rather than grouping policy panels by substance, an effort will be made to organize panels around common theoretical approaches. The purpose is to enhance the interaction across fields of substantive interest in an effort to advance the state of public policy theories. Although the section is open to all topics in public policy, special emphasis will be given to three types of proposals. First, public policy studies are often divided into normative and empirical analyses.
Such a distinction needlessly limits the audience and the form of analysis for policy studies. Preference will be given to studies that blend both normative and empirical approaches to public policy. Second, political scientists tend to emphasize the determinants of public policy leaving questions of implementation and impact to others. By linking politics and public policy to policy outcomes (rather than just policy outputs), the study of public policy can make valuable contributions to the design of new public policies. Preference will be given to studies that link public policy activities to policy outcomes. Third, preference will be given to studies that have passion.

Proposals to present papers should include an abstract that specifies (1) the theoretical approach used, (2) the type of analysis undertaken, (3) the substantive area or areas addressed, and (4) the importance of the study.

\section{Political Economy: Miriam} Golden, Department of Political Science, UCLA, Los Angeles, CA 90024; 310-206-8166 (office); 310825-4331 (dept); 310-825-0778 (fax); GOLDEN@CADY.SSCNET.UCLA.EDU (e-mail).

Political economy encompasses two distinct research agendas. One concerns the substantive intersection of economics and politics. The other uses economic models to analyze political phenomena. Initially, these two agendas were largely pursued by different scholarly cohorts, often with little dialogue between them. This engendered intellectual losses for both, which are only now being reversed thanks to research efforts that deliberately seek to employ elements of both approaches.

My priority in arranging panels will be to encourage this dialogue by bringing together representatives of these two methodological perspectives. Single paper proposals from either are welcome. For instance, paper proposals may concern work that draws on either historicalinstitutional or formal-deductive methods. Proposals for whole panels, by contrast, should include participants from both research perspectives. Proposals for papers, for panels, or for roundtables that bridge the traditional field boundaries in 
political science (American politics, comparative politics, international relations) are also especially appropriate to a field such as political economy. Finally, I welcome offers to serve as discussant by those interested in spanning the diverse methodological approaches found in political economy.

\section{Women and Politics: Christine Di Stefano, Department of Political Science, DO-30, University of Wash- ington, Seattle, WA 98195; 206-} 543-9254 (office); 206-685-2146 (fax).

The theme for the 1994 meeting, "Politics and Political Science in a Changing World," offers a unique opportunity to showcase research and theory on women and politics.

Women and politics research is closely affiliated with the theme of change in a number of respects. It is often the case that research on women instigates changes in our conceptions of the discipline. Theoretical paradigms, established methods and models, working vocabularies, disciplinary boundaries, and subfield designations within the discipline have all come under critical scrutiny and refurbishing as a result of research on women. Many of us involved in research on women and politics are also motivated to pursue such research because of a commitment to changing and improving women's status. Finally, recent trends in the United States and abroad signaling political changes of potentially significant import invite sustained investigation and analysis regarding women's role in the development of such changes and the impact of such changes on women's lives. How is research on women and politics changing the discipline of political science? What can research on women and politics tell us about those factors that impede and enhance women's prospects for empowerment? To what extent are women gaining or losing political ground as a result of political changes?

Papers and panels which explore the impact of economic and political changes in Eastern Europe and the former Soviet Union on women are strongly encouraged. To what extent does the language of "democratization" conceal the fact that women are losing political ground? How are women faring in the transition from socialist to capitalist economies? Comparative and cross-cultural research on women's political behavior, social movements, and status in other parts of the world is also encouraged. In the aftermath of the 1992 U.S. elections and the much-touted "Year of the Woman," papers which analyze the implications of the changes in administration at federal and state levels for women's policy issues will be welcome, along with those that pursue the question of "the difference" that women elected and appointed to public office make.

In addition to panels that showcase new and ongoing research on women and politics, I encourage the submission of papers that take a critical and reflective stance on the implications of such research for the discipline and its subfields. Recent feminist contributions to international relations theory, for example, suggest the need to significantly revise reigning theories and models. I also welcome papers in feminist theory that develop and/or analyze changes in modes of feminist theorizing, particularly as these involve such concepts as "gender," "identity," "women," and "power." Papers in feminist theory that draw on and address empirical research on women are encouraged.

I will welcome proposals for complete panels as well as individual papers and would like to have at least one special panel or roundtable devoted to a "classic" work in the field of women and politics. Proposals for papers that deal with themes not explicitly mentioned here will also be given due consideration.

\section{Race, Gender, and Ethnicity:} Katherine Tate, Department of Political Science, Ohio State University, Columbus, $\mathrm{OH}$ 43210-1373; 614292-2800 (office); 614-292-1 146 (fax).

Race, gender, and ethnicity represents an important subfield of political science that cuts across all four of its major fields, namely political theory, American politics, comparative politics, and international relations. Suggestions for panels, papers, or roundtables that touch on race, gender politics, or ethnic politics are solicited. Based on past conventions, I expect to have several panels devoted to minority politics in the United States.

The Association's theme for its 1994 Convention is "Politics and Political Science in a Changing World." With this in mind, I highlight three potential research areas that have been underrepresented at past conventions. These issues, by no means, represent all that should or can be addressed in the study of race, gender, and ethnicity. First, I encourage proposals that address the intersections of gender and race, gender and ethnicity, or race and ethnicity. Such groupings have generally been overlooked by social scientists in their efforts to deal with separately the concepts of "race," "gender," or "ethnicity." For that matter, I will consider proposals dealing with sexuality and politics as well.

Second, the rise of nationalism represents without question the most serious development of the New World Order. Eastern Europe, republics of the former Soviet Union, Somalia, and Cambodia are but some of a growing number of regions and countries recently beset by violence and ethnic-based warfare as a result of ethnic conflict. Moreover, conflict and tension between "minorities" and "majorities" have intensified n Western Europe as well, giving rise to new issues, new voting patterns, and new parties. How different is nationalism found in "advanced" industrial societies (e.g., Spain, Canada, or Northern Ireland) from that found in less developed states (e.g., Sri Lanka, India, or Brazil)? Is racial or ethnic conflict rooted more in psychology or economics? And in terms of political theory, does group autonomy or selfdetermination interfere with modern democratic processes? Proposals for a roundtable or complete panels focused on the longstanding debate over modernization and the rise of nationalism are also invited.

Finally, women have figured prominently in the transformation of world politics and political systems. And yet, political history and political science have had relatively little to say about their unique contributions. Some of the issues that can be 
addressed in 1994 include: How has feminist thought or the women's political movements affected public policy or the development of the modern state? Were the elections of women in the 1992 elections reflections of female anger against the political system or the fruits of longterm efforts?

\section{Politics and History: Ellen} Immergut, E53-365, Department of Political Science, Massachusetts Institute of Technology, Cambridge, MA 02139; 617-253-3138 (office); 617258-6164 (fax).

Proposals are invited for papers, panels, and roundtables that examine the intersection of history and politics. For 1994, topics of special interest include: (1) defining the distinctiveness (if any) of the use of historical inquiry by political scientists; (2) transformations in the relationships between domestic and international politics in historical perspective; (3) the contributions of political/historical analysis to an understanding of contemporary public policy; (4) contested notions of identity and interests including those concerned with gender, race, and class.

As always, we welcome papers concerned with American political development. But we hope, as well, to include papers that span traditional divides not only between politics and history but also between the areas of American politics, comparative politics, and political theory.

22. Comparative Politics: Robert Kaufman, Department of Political Science, Rutgers University, New Brunswick, NJ 08903; 908-932-9280 (office); 908-932-7170 (fax).

Is there anything more to comparative politics than the study of foreign governments? We welcome proposals for panels, papers, and roundtables which offer convincing, or at least interesting, affirmative answers.

Proposals on a wide range of topics will be considered, particularly if they provide a cross-national focus. Themes that will receive special attention are: (1) the restructuring and viability of nation states; (2) the connection between democratic institutions and market- oriented reforms; (3) evolving definitions of national identity and citizenship; and (4) the relation between international influences and domestic political change.

Among the methodological issues that might be addressed are: (1) advantages and problems of crossregional comparisons; (2) units of comparison: the utility of the conventional focus on national political systems as distinguished from suband transnational systems and processes, specific institutions, or individual behaviors; (3) comparative method and design: uses of large-n statistical studies, case studies, smalln comparisons; (4) key explanatory variables and approaches: the role of the state and political institutions, political culture, rational choice.

\section{Politics of Developing Areas:} Mitchell Seligson, Department of Political Science, University of Pittsburgh, Pittsburgh, PA 15260; 412647-7268 (office); 412-648-7277 (fax); SELIGSON@PITTVMS (e-mail).

Democratization and development are two overall themes that I would like to encourage for the 1994 APSA meeting. I would hope that the proposals would be genuinely comparative rather than single-country case studies, but I will consider panels in which a series of case studies deal with a single, cohesive theme. Since this division concentrates on developing areas, I would prefer to accept panels that have at least one participant from the area being studied. Panels chaired by such individuals are especially encouraged.

Within these broad themes, I see opportunities at both the micro- and macrolevels. One major challenge on the microlevel in the democratization area is that presented by Eckstein, who has argued that we must test the validity of the political culture thesis vs. the rational choice thesis. Political culture, only recently relegated to the "back burner" of the field, has now become a central issue of study. Much of this new interest in the subject is a function of the sudden democratic opening in formerly authoritarian systems, and the resulting explosion in freely conducted public opinion polls. Unfortunately, many of these studies are seriously flawed in design, execution, and analysis. At the 1994 APSA I hope to hear several papers reporting on the political culture of developing nations in which the rigorous standards common to public opinion work in the United States and Western Europe have been approximated.

A second challenge in democratization and development, moving to the macrolevel, is that data bases are now available for a larger number of countries over an expanded period of time. In the 1980s we were absorbed testing variants of the dependency thesis, and its impact on democracy, as well as development. Today we can move beyond that focus to test some of the more provocative theses that have arisen, especially those that focus on rent-seeking, urban bias, and other policies that are thought to limit growth and increase inequality. With the recent availability of previously secret data from Eastern bloc countries, work that reexamines the question of income inequality within socialist states becomes particularly interesting.

A third challenge involves classifying the former socialist states. Are they, as has been suggested, underdeveloped countries with a veneer of (antiquated) industrial infrastructure, or are they developed countries that have been mismanaged? This issue forces us to reexamine once again our definitions of development and underdevelopment.

A fourth challenge is in the field of the environment. Some of the worst cases of environmental destruction are found in the developing nations. Those conditions are rapidly worsening as export agriculture demands greater use of pesticides and other chemicals. Yet, it is these very nations that can least afford costly environmental legislation.

A fifth challenge is that of the impact of ethnic conflict on both development and democracy. Ethnic conflict today threatens to shortcircuit democracy and inhibit economic development. Yet, ethnicity was a variable that for many years tended to get swept under the rug both within the "melting pot" mentality of the United States and the enforced conformity policy of the socialist states. Today we know how wrong we were, and yet political sci- 
ence still seems enamored of the strong nation-state that can contain such conflicts.

Responses to all of these challenges will require studies that are rigorous in their methods, yet sensitive to the great variety of cultural traditions around the world. Panels that evidence both characteristics are most likely to be selected.

\section{Politics of Former Communist and Communist Regimes: Ellen Mickiewicz, Department of Political Science, Emory University, Atlanta, GA 30322; 404-727-6572 (office); 404-727-4586 (fax).}

In the formerly Communist world, change has been rapid and dislocating. In currently Communist societies, there is an expectation of change of unknown proportions. Inevitably, this process generates a re-thinking of both the theoretical underpinning of the study of Communist and postCommunist systems and the fit of more broadly comparative models and is aided by new access to data sources (though increasingly costly and subject to the effects of new nationalisms). In many cases change is the result, often unintended, of the deliberate application of nonindigenous models (and consultants) in the policy process of democratization and/or economic development. In the post-Cold War world, former Communist and Communist foreign policy and the security component search for new foundations and reflect new internal conflicts. The papers and panels that contribute to an understanding of these broad developments are especially encouraged. Priority will be given to papers developing solid theoretical and empirical work on the dynamic of these topics and their interrelationship.

Below are areas of substantive interest. The specific examples clearly may relate to more than one of the areas.

(1) Federalism, Regionalism, and Ethnopolitics: institution-building, electoral systems, legislative politics, political parties, political identity.

(2) Political Economy: reform; international interactions at national and subnational levels; effects of new technologies, trade, and aid on state- building; sovereignty and interdependence.

(3) Transitions and the consolidation of new systems: political and legal structures, public opinion, political communication. In addition, papers that shed new light on the continuing discussion of totalitarianism and sources of the liberalization or dissolution of Communist systems will be favored, particularly if they address the classic analyses that shaped the field.

(4) Foreign policy and national security: domestic sources of policy, nuclear arms proliferation, roles of international regimes and organizations.

\section{Comparative Politics of} Advanced Industrial States: Russell Dalton, Department of Politics and Society, University of CaliforniaIrvine, Irvine, CA 92717; 714856-6569 (office); 714-856-6336 (messages); 714-856-8441 (fax); RDALTON@UCI (e-mail).

While the rest of the world has experienced amazing transformations in the early 1990s, advanced industrial societies also have been part of this changing world-affected by these global processes and undergoing their own internal changes. The issues and political questions that seemed so pressing a decade ago often appear in a different light in this new political context. Although all papers on the comparative study of advanced industrial states are welcomed, the section organizer wants especially to encourage submissions in three broad areas:

First, how are on-going internal processes of social, economic, and political change in advanced industrial societies affecting the processes of democratic decisionmaking? This area might include studies of the changing role of technology and the media on politics, the impact of value change, neo-conservative movements, changes in the nature of voters and political activity in these societies, and similar phenomena.

Second, are there significant structural or policy changes within advanced industrial societies that are reshaping the content and nature of the political process? This category might include panels on the restructuring of party systems in the post-
Cold War era; assessments of the welfare state policies in a postwelfare state era; changes in the structure of interest intermediation, such as the rise of citizen interest groups and PACs; and comparative studies of policy innovation in our changing world.

Third, how are global forces of change impacting on the politics of advanced industrial societies? This area might include research on how global environmental problems, international trade, or migration issues are affecting advanced industrial societies. The development of structures such as European Community and NAFTA represent other examples of international influences on national politics.

The section encourages explicitly multi-nation panels, especially those which span more than one geographic region (such as Europe and North America). In addition, research which addresses the interaction of domestic and international forces on political processes is encouraged. These suggestions are not, however, meant to limit the range of submissions; other proposals within the general theme of advanced industrial societies are welcomed. Proposals for panels will be given priority.

\section{Politics and Society in Western} Europe: Kathleen Thelen, Department of Political Science, Princeton University, Corwin Hall, Princeton, NJ 08544-1012; 609-258-5239

(office); 609-258-4772 (fax).

The panels and papers in this division should explore important theoretical, methodological, or empirical issues relating to West European politics and society. In keeping with the theme of the 1994 meetings, I encourage especially panel and paper proposals that confront in a theoretically informed way the institutional and political changes that have been reshaping politics, society, and the economy in Western Europe over the past two decades, including (but not limited to) changes in party politics, electoral alignments, social and class structures, social movements, organized interest groups, industrial relations, and the welfare state, as well as changes associated with European integration and their implica- 
tions for political relations among and within West European countries. However, this list is by no means exhaustive, and I welcome work on other topics as well as more historical themes. Panels and papers that are explicitly comparative (including those that compare developments in Western Europe with those in other regions or countries) are strongly encouraged.

Proposals from the full range of quantitative, qualitative, and formal approaches are invited. I will give priority to proposals that explicitly explore the usefulness of competing methodologies, reevaluate conventional concepts and analytic frameworks, or rely on innovative comparisons. I am particularly interested in receiving proposals for panels that involve a focussed evaluation of competing approaches, for example, by examining a common empirical question from different methodological or theoretical angles.

Panel proposals should provide synopses for the individual papers as well as a statement of the overarching theoretical themes that unify the panel as a whole. Where possible, proposals for panels should leave room for an additional paper to be added from among paper proposals submitted separately.

27. International Collaboration: Jack Donnelly, Graduate School of International Studies, University of Denver, Denver, CO 80208; 303871-2563 (office); 303-871-2456 (fax); JDONNELL@DIANA.CAIR.DU.EDU (e-mail).

The end of the Cold War and the (not entirely unrelated) decline in the popularity of realist theories of international relations have made questions of international collaboration increasingly central to contemporary international theory and practice. But to take full advantage of the prospects that this new political and intellectual environment offers for deepening our understanding of international cooperation, we must move beyond general overviews of the fact of dramatic international change to deeper and more detailed accounts of the specifics of such changes. In particular, programmatic statements of the reality and importance of international cooperation are no longer enough. We need constructive, theoretically informed analyses of particular collaborative processes. Likewise, we can no longer settle for critiques of the myopia of realism. We need positive theoretical and empirical work that concretely demonstrates the utility of alternative approaches.

Contributions from all disciplinary perspectives and subfields are encouraged. Special consideration, however, will be given to proposals that emphasize the role of institutions, ideas, or values. In addition, papers that apply social constructionist approaches, broadly understood, probably will fit more comfortably in this section than in the other international relations sections of the program.

Early submissions are encouraged. All proposals for papers or panels, as well as offers to serve as panel chair or discussant, should be accompanied by a c.v. Proposals from graduate students should also include either a draft of the proposed paper or a sample dissertation chapter.

\section{International Security and Con-} flict: Richard Eichenberg, International Relations Program, Cabot 605, Tufts University, Medford, MA 02155; 617-628-5000, x 2776 (office); 617-628-5508 (fax); REICHEN@PEARL.TUFTS.EDU (e-mail).

This division is defined broadly to include theoretical and methodological approaches to the causes, outcomes, and consequences of conflict in international relations, including the related issue of order-building in an anarchic system. Given the plethora of actual and potential conflicts now appearing in the global system of the post-Cold War era, it would seem a propitious moment to re-examine the adequacy of our theories, assumptions, and concepts. Accordingly, I particularly invite proposals for papers, panels, or roundtables that address fundamental issues:

(1) the overall conference theme of "Politics and Political Science in a Changing World";

(2) the adequacy of "classics" of international relations theory or other theories of conflict and security (for example: the adequacy of integration theory to sort out the com- peting trends of integration and disintegration in regional systems, or the adequacy of deterrence theory in light of recent global changes);

(3) the adequacy of fundamental concepts in the field of international relations and security (rationality, sovereignty, order, institutions, security, conflict);

(4) the adequacy of standard methodologies - formal and empirical -employed in the past to understand security and conflict.

Of course, I also welcome proposals for papers and panels that deal with specific theories of conflict and security; with specific regional or other conflicts, including historical studies or studies from other disciplines; or with "new"types of international conflict. Given the trends in scholarship in the field, panels and papers that deal with the relationship between domestic politics and international conflict and security are particularly welcome.

29. International Security and Arms Control: Joyce Kaufman, Department of Political Science, Whittier College, Whittier, CA 90608; 310907-4200 (office); 310-698-4067 (fax).

The world is changing. Nowhere is this change more profound than in the area of international security. Security can no longer be defined in narrow terms, but must be addressed in ways that are more appropriate to the challenges that are continuing to emerge. The break-up of the Soviet empire and the end of the Cold War, the use of military force to deliver economic aid and relief, and the emergence of economics as a critical instrument of power, are but a few obvious examples. After more than 45 years, the United Nations has become a viable international force, playing a number of important roles throughout the world, while other questions emerge about the role of traditional alliances, such as NATO, in a changing world.

This is also a world in which the stability of the Cold War period has been replaced by instability and conflict. The growth of nationalism, ethnic rivalries, and internal domestic conflicts are increasingly threatening global stability. Internal problems and issues warrant international attention, as these problems cross 
borders, and raise issues of global concern.

The theme for the 1994 APSA meeting, "Politics and Political Science in a Changing World," seems especially apt here. Proposals for panels, roundtables, and individual papers are welcome in the area of security, broadly defined. In particular, we are interested in proposals which address aspects of the following:

(1) The likely sources of conflict, and possibilities of conflict resolution, in an international system in transition. Special attention will be given to the areas of ethnicity, nationalism, and the transition of the traditional nation-state system. What are the likely sources of conflict, and the relationship between domestic and international conflicts? What is the role of collective security in a changing international environment? What are the prospects for "peacekeeping" and negotiation in averting, or resolving, conflict?

(2) Can we predict the future? The prospects for alliances and realignment in a post-Cold War environment. This might include military relationships and the growth of economic unions, as well as the role of supra-national organizations.

(3) What will replace the Cold War as the framework within which to approach the study of security issues, defense policy and arms control? Do events of the past few years support the argument that bipolarity is a more stable system than multipolarity? Here we are interested in addressing regional issues, general questions of multipolarity versus bipolarity, and a rethinking of some of the basic paradigms and approaches in the field.

(4) While the United States and Russia are actively involved in arms control and decreasing their own nuclear stockpiles, other countries are moving toward the proliferation of nuclear, biological, and chemical weapons. North Korea, India, Pakistan among others call into question some of the basic premises of the existing treaty relationships, and raise additional questions about where the technology and materials are coming from. What strategies and/or options are available to stem this tide of proliferation? Why are non-nuclear weapons states seeking to acquire nuclear weapons? In a multi-polar system, with regionally subdivided security structures, what are the preferred regime structures for: (1) nonproliferation or weapons of mass destruction, (2) high technology conventional weapons, and (3) the transfer of technology that support the above?

\section{International Political Economy:} Vinod K. Aggarwal, Department of Political Science, University of California-Berkeley, Berkeley, CA 94720; 510-642-2817 (office); 510642-9515 (fax).

Proposals for panels, papers, and roundtables are invited in all areas of international political economy.

These may include:

(1) examinations of theoretical debates in the field and/or presentation of new theoretical perspectives;

(2) analytical examinations of issue areas in international political economy including trade, monetary issues, investment, the environment, energy, and linkages of economic and security issues, both current and historical; and

(3) Policy papers that draw clearly upon some theoretical body of knowledge in international political economy.

In keeping with the theme of the meetings on "Politics and Political Science in a Changing World," proposals for panels that examine the implications of the demise of the Soviet Union, ethnic conflict, and the debate over the regionalization of the world economy for international political theorizing are particularly welcome. Different methodological approaches including formal models, statistical analyses, case studies, and computer simulations are welcome. Papers analyzing individual countries or domestic policy issues should bear upon some theoretical or empirical issue in international political economy.

\section{Foreign Policy Analysis: Richard} Herrmann, Department of Political Science, Ohio State University, Columbus, OH 43210-1373; 614292-8196 (office); 614-292-1146 (fax).

Panels and papers that advance theoretical, interpretive, and substan- tive concerns are welcome as are those which promote analytical and methodological interests. In line with the conference theme, panels and papers that deal with the causes and consequences of foreign policy change are especially encouraged. The following four general topic areas, among others, will receive attention.

(1) Foreign policy decisionmaking, including both theoretical and substantive work examining the individual, group, and bureaucratic processes that are involved in the construction of policy options and the selection of choices. Among other topics these might include papers that deal with the political psychology of perceptions, the effects of nationalism and changing community identities, group processes, bureaucratic politics, and models of information processing, representation, agenda setting, advisory networks, and policy choice.

(2) Domestic determinants of foreign policy, particularly work that concentrates on the relative importance of domestic determinants, the interaction between domestic process and external developments, and the domestic political requirements for coalition maintenance, political governance, and economic growth.

(3) Comparative foreign policy, especially studies that concentrate on change in a comparative perspective, work that breaks new substantive and interpretive ground in interesting cases, and efforts that examine comparative adjustments to the changing political environment or examine how these adjustments might best be studied.

(4) Systemic determinants of foreign policy, including studies that examine the responses in foreign policy to global problems in the environment, economy, or world system. Papers that analyze foreign policy within the context of an interactive setting, whether done in formal game theoretic terms or more substantive narrative form are encouraged.

\section{Representation and Electoral} Systems: Richard Engstrom, Department of Political Science, University of New Orleans, Lake Front New Orleans, Louisiana 70148; 504-286- 
6671 (office); 504-286-6468 (fax); RLEPO@UNO.EDU (e-mail).

Panels for this section will continue to cover representation and electoral system issues not only in the United States but in other democracies as well. One panel will be devoted to the recent Supreme Court decisions concerning the Voting Rights Act. This panel will focus on the implications of Voinovich $v$. Quilter (Ohio), Growe v. Emison (Minnesota), and Shaw v. Barr (North Carolina). Other panels may concern more general issues raised by the recent round of computer-assisted redistricting, such as the importance, if any, of a compactness criterion in the determination of representational district boundaries. Papers examining the work of reapportionment agencies other than state legislatures, such as bipartisan commissions with or without tie-breakers and federal court panels, would also be welcomed.

At least one panel will also be devoted to the analysis of changes in electoral systems around the world. This may include the switch from proportional representation to a firstpast-the-post system in Italy, and then switch from a first-past-the-post system to a proportional arrangement in New Zealand. It could also focus on the initial experiences with democratic election systems in eastern Europe. Papers concerning districting practices and policies within other democracies would also be welcome, particularly investigations of the work of the parliamentary boundary commissions in the United Kingdom and Canada.

These topics do not exhaust the possible range of substantive concerns that the panels will address. Paper proposals on other topics, normative and/or empirical, are encouraged.

33. Conflict Processes: T. Clifton Morgan and Richard J. Stoll, Department of Political Science, Rice University, P.O. Box 1892, Houston, TX 77251; 713-527-4842 (office); 713-285-5161 (fax); STOLLA@RICEVM1 (e-mail).

In spite of the end of the Cold War and the widespread belief that a new world order has arisen, the international system continues to experience a great deal of conflict. Whether or not the dramatic changes in the international system have even produced a transformation in the processes by which conflicts arise and evolve is the subject of much debate. We welcome proposals for papers, panels and roundtables that address questions regarding the causes, conduct, and resolution of domestic and international conflict. While papers dealing with all aspects of the subject are appropriate, we are particularly interested in those examining how variations in the international system and the states within that system affect conflict processes.

We seek proposals from a wide range of substantive and methodological perspectives. Papers can focus on general patterns of conflict behavior, on specific types of conflict, or on conflict within particular geographical regions or nations. Furthermore, papers can be primarily theoretical in nature, focus on empirical questions, or address practical issues. Finally, we are interested in receiving proposals for papers that examine the connection between conflict and other areas within political science, such as domestic politics or political economy, or other academic disciplines, including psychology, sociology, history, and economics.

Anyone wishing to organize a panel or roundtable is encouraged to communicate with us prior to formal submission of the proposal.

\section{Politics and Life Sciences: John} M. Strate, Department of Political Science, Wayne State University, Detroit, MI 48202; 313-577-2649 (office); 313-577-1274, plus dept. name and phone number (fax); JSTRATE@WAYNEST1 (e-mail).

The life sciences have made many contributions to our understanding of politics and the discipline of political science. Proposals are welcome for papers or roundtables from any area of politics and the life sciences, especially those building upon the general theme of politics and political science in a changng world.

On the theme of politics in a changing world, topics might include biotechnology policy (e.g., altered plants and animals, recombinant
DNA, the Human Genome Project) and biomedicine and health policy (e.g., abortion, AIDS, Darwinian medicine, euthanasia, genetic engineering, genetic screening, health care systems, neonatal care, prenatal intervention, surrogate contracts). Another topic might be the future of the biosphere and of $H$. sapiens in an era of global capitalism (e.g., deforestation, exhaustion of nonrenewable resources, food shortages and famine, global warming, air and water pollution, ozone depletion, population growth and movement, soil erosion, species extinction, toxic waste disposal).

On the theme of political science in a changing world, topics might include new developments in the study of physiological variables and political behavior and in the study of political behavior through direct observation. Another topic might be the growth of sociobiology and its intersection with political science and policy. Multidisciplinary panels are encouraged that bring together participants from the social sciences, medicine, biology, law, bioethics, and philosophy.

Another possibility is a roundtable that explores the contributions that biopolitics has made to major areas of political science, contrasts the approach of biopolitics with more traditional approaches, and outlines a future research agenda. Such major areas might include political thought and philosophy, law and the courts, women and politics, race, gender and ethnicity, and international security and conflict.

\section{Religion and Politics: Allen} Hertzke, The Carl Albert Center, 630 Parrington Oval, Room 101, University of Oklahoma, Norman, OK 73019-0375; 405-325-6372 (office); 405-325-6419 (fax); na0171@uokmvsa.backbone.uoknor.edu (e-mail).

In keeping with the theme of "Politics and Political Science in a Changing World," I encourage papers and panels that deal with the religious contribution to political change and the impact in turn of political change on religion. This theme lends itself well to comparative politics research in light of rapid and 
explosive change around the globe. It also focuses us on the changing landscape of American politics-on partisan alignments and shifting pressure group politics nationally, and on increasingly important state and local battles over abortion, school curricula, educational choice, gay rights ordinances, euthanasia referenda, etc., that constitute skirmishes in the "culture wars."

All methodological approaches are welcomed; indeed, I will endeavor to form topical panels that span behavioral, institutional, cultural, and historical methods. Papers on churchstate relations, constitutional law, and normative theory are welcome, but preference will be afforded to those that link such discussion with the theme of political change and our attempts to understand it.

Proposed whole panels are invited, especially roundtables and special panels that would serve to present the broad theoretical insights of the religion and politics field to those in other fields. Panels on the state of the discipline, alternative theoretical explanations, author meets critic, and discussion of classic themes or works, will be given serious consideration. Individuals with ideas about such panels or interest in participating in them, should contact me.

36. Applied Political Science: Nolan E. Jones, National Governors Association, Hall of States, $444 \mathrm{~N}$. Capitol Street, N.W., Suite 267, Washington, DC 20001-1512; 202624-5360 (office); 202-624-5313 (fax).

The theme for the 1994 annual meeting, "Politics and Political Science in a Changing World," presents an opportunity for applied political science to focus on the role played by political science in the events that have changed the world during the last few years. Proposals for papers and panels could reflect on a single event such as the American elections of 1992, or a combination of events, from an applied political science perspective.

Some questions to consider are: What does applied political science have to offer in dealing with modern social problems, such as crime and violence, social welfare, and health care? Is the applied perspective on these issues different from traditional political science research? Could the contribution of the applied perspective offer new insight into these issues? Would it help if applied political science had greater acceptance within the discipline?

The applied sections in other social science disciplines have begun to tackle some of these issues, focusing on implementation and consequences. Perhaps applied political science could review political science research and evaluations from a similar point of view.

37. Science and Technology Studies: Richard Worthington, Department of Political Science, Pomona College, Claremont, CA 91711-6336; 909621-8189 (office); 909-621-8576 (fax); RWORTHINGTON@POMONA.CLAREMONT.EDU (e-mail).

Through most of its history, the STS division has focused on questions quite relevant to the theme of the 1994 meetings, "Politics and Political Science in a Changing World." Recurring themes in our deliberations over the past five years have included the nature and significance of S\&T as a problem focus in political science; the interdependencies of scientific and political institutions and endeavors, and the consequences of their interactions for social well-being; the roles for political science research in S\&T policymaking; and the role of technology in international change.

We welcome panel and paper proposals on all aspects of science, technology and politics. A question that addresses the 1994 theme and builds on the division's discourse to date is "What is the role of our inquiries in a changing world?" Suggested topics include (1) Technology and freedom, 1994-how do developments in telecommunications, multimedia, biotechnology, and other technological arenas affect privacy, creativity, repression, community, and power relations? (2) Are Democrats different?-Nearly two years after 12 years of Republican leadership in the White House, what continuities and departures in S\&T policies and trajectories are visible? (3) Political science and STS-What are the best and worst trends in each of these fields given the challenges of a changing world? (4) Political reconstruction of technology - What do we know about the politics of guiding technological change? Where (if anywhere) is this knowledge evident in political practice?

(5) Global Change-How can our conceptual frameworks help us understand the relationships of people and nature at a global level, as well as options for managing these relationships on an equitable and sustainable basis? Case studies of NAFTA, EC, the Rio Conference, and other regional/global initiatives are especially appropriate.

Participation by practitioners and scholars outside political science is encouraged. The division sponsors a research workshop each year the Wednesday of APSA meeting week, and suggestions for topics and participation are welcome.

\section{Computers and Multimedia:} George Watson, Department of Political Science, Arizona State University, Tempe, AZ 85287-2001; 602965-6551 (office); 602-965-1608 (fax); ATGLW@ASUACAD.BITNET (bitnet).

The theme for 1994, "Politics and Political Science in a Changing World," plays well to the Computers and Multimedia division. I seek one roundtable discussion panel this year that addresses how computers and multimedia are changing higher education in general and political science education in particular. Participants in this panel should be able to help the rest of us understand where technology is taking us in our roles as continuous learners and as teachers.

If the roundtable is designed to tell us what lies in our future, more traditional panels will permit us to see where some of our colleagues presently are. Proposals for participation are invited from those who wish to present papers, give presentations as part of a panel, or serve as panel discussants on any number of topics focusing on the role of computers and/or other media for teaching or research purposes. Appropriate topics might include, among others: research on the effectiveness of various computer and media applications in the promotion of learning; creative applications of computers and media in educational set- 
tings; creative development of computer and media applications for research or educational purposes; research applications of new or existing hardware, software, or multimedia resources; evaluations of existing statistical, multimedia, or other computer or media-based packages. Proposals specific to other subfields within the discipline are encouraged. Finally, proposals for workshops conducted just prior to the meeting or for demonstrations of computer and/or multimedia applications are also invited.

Paper, presentation, and demonstration proposals should include an abstract outlining the major elements of what is proposed and specify in detail any equipment needs. Roundtable participants should indicate what their participation would contribute to the roundtable topic.

\section{Political Communication: David Swanson, Department of Speech Communication, 244 Lincoln Hall, University of Illinois, Urbana, IL 61801; 217-333-2683 (office); 217- 244-1598 (fax); DSWANSON@- UIUCVMD.BITNET (e-mail).}

The study of political communication is concerned with relationships between processes and structures of politics and of communication. We welcome proposals for papers and panels representing the full range of disciplinary perspectives, research questions, and scholarly methods that can advance understanding of this multifaceted subject. We hope to receive proposals that offer diversity in: units of analysis, from individual cognitive processing of political information to comparative studies of national political communication systems; methods, from textual analysis to large-scale social surveys; contexts, from electioneering to governing to the political consequences of popular culture; viewpoints, from normative interests in democratic processes to technological interests in political communication practices; actors, from voters to political journalists and professionals to elites and political leaders; and intellectual traditions, from rhetorical and critical work to policy studies to socialscientific approaches to public opinion and the political effects of mass media.
The theme of the 1994 meeting concerning a changing world calls attention to recent and ongoing transformations in political communication practices in the United States and in modern democracy generally. We encourage especially proposals that address the conference theme, employ comparative or interdisciplinary approaches, or offer significant theoretical or methodological contributions. Given panel limitations, we also encourage proposals that are appropriate for cosponsorship with other program units.

\section{Transformational Politics: John} Rensenbrink, Bowdoin College, Environmental Studies Program, Brunswick, ME 04011; 207-725-3367 (office); 207-725-3123 (fax).

APSA has adopted as its theme for 1994 "Politics and Political Science in a Changing World." This theme is highly relevant to the theoretical and practical concerns of the Transformational Politics division. It is an especially interesting theme, as well, because so many of the efforts of classic "systems" analysts and others to deal with fundamental change proved disappointing to most of us. What went wrong?

Papers are invited on themes that address the relationship between change and transformation, and the possible meanings and implications of both concepts. We seek papers that address some aspect of two general topics:

(1) Are change and transformation the same? If not, how and why do they differ? What are the implications, for the discipline of political science, of a transformational approach to change?

(2) What are the transformational meanings and prospects of the changes that are taking place in the fields of (a) political culture (for example, in its psychological and social dimensions, in religious and spiritual life, in the arts, in education); (b) environmental policy and problems; (c) social and political movements for change; (d) comparative and global politics; and (e) political theory?

41. New Political Science: Stephen Bronner, Department of Political Science, Rutgers University, New Bruns- wick, NJ 08903; 908-932-9327 (office); 908-932-7170 (fax).

The purpose of this section is to bring together those individuals who identify with a critical and activist approach to the study of political science. We seek papers across the broadest possible spectrum of the discipline. But we expect these papers will share the conviction that the study of politics is never value-free, and that political scientists, whatever their field or focus, have an active responsibility to connect their understanding to the search for human betterment and social justice.

In addition to proposals for papers and/or panels that incorporate the 1994 meeting theme of "Politics and Political Science in a Changing World," we are generally interested in the following areas:

(1) Currents in critical political theory, including discussions of neoMarxism, critical theory, the politics of culture, feminist theory, and the idea of a new political science.

(2) Contending perspectives on democracy and development, including discussions of Latin America, Asia, Middle East, Africa, women in the third world.

(3) Racial and ethnic politics.

(4) The politics of gender.

(5) International political economy, political responses to the globalization of the economy, intervention in third world politics.

(6) Urban political economy, community politics.

(7) Social movements in Western Europe and America, political transformation in communist systems, agendas for the left.

If there are other topics or themes in which you would be interested, we invite your suggestions and proposals.

\section{Political Psychology: Richard} Lau, Department of Political Science, Rutgers University, New Brunswick, NJ 08903; 908-932-9250 (office); 908-932-7170 (fax).

Political psychology exists at the intersection between the disciplines of political science and psychology, and I am particularly interested in papers or, better yet, organized panels, that illustrate the mutual benefits that come to both disciplines from such 
interdisciplinary efforts. I hope to have panels that will look at both mass and elite, and the linkages between the two, using methodologies as diverse as computer simulation, experiments, focus groups, indepth analysis of one or a few actors, surveys, and so on. Most political psychology research is conducted in the subfields of voting behavior and international relations, applying theories of individual psychology to actors in those two subfields, and I expect most panels to have one or the other focus. But political psychology has much to contribute to the study of groups and organizations as well, and to individual political actors in other subfields, and I hope to see papers or panels that take a psychological perspective addressing topics in political culture, public law, institutional behavior, social movements, feminist theory, and so on. I would hope that we could interest political psychologists who rarely come to APSA to either contribute papers or serve as discussants at the upcoming meeting in New York, and I will do my best to get such individuals to participate. Help in this effort is appreciated.

43. Politics and Literature: Mary P. Nichols, Department of Political Science, Fordham University, Bronx, NY 10458; 718-579-2317 (office); 718-367-9404 (fax).

In accordance with the APSA's theme, we are soliciting papers addressing the role of literature in a changing world. How has literature throughout history dealt with issues of change and stability, revolution and preservation? What is unique about our changing world, and is literature of any help to us in understanding or directing change? If history is moving toward a democratic world order, what different kinds of democratic arrangements are possible or desirable? How can literary works help us to better understand the problems that democracies face? What can poetry in the broad sense (drama, novels, etc.) tell us about liberty, equality, and participation, about individual rights and the search for community?

Martin Heidegger criticized Western philosophy while suggesting poetry as an alternative to the dom- inant technological way in which modern men and women approach the world. Is there any validity to his suggestion that philosophers and scientists have much to learn from poetry? Should poetry make a difference to how political scientists in particular view the world? What is the relation between philosophy and poetry? Is truth better revealed by poetic expression or philosophic thought? In light of Heidegger's philosophic defense of poetry, papers exploring "the ancient quarrel between philosophy and poetry" would be especially welcome, from the perspective of poets or philosophers, ancient or modern.

\section{Internships and Experiential Education: Roberta Johnson,} Department of Political Science, University of San Francisco, Ignatian Heights, San Francisco, Ca 94117; 415-666-6296 (office); 415-666-6784 (messages); 415-666-2346 (fax).

There are some political scientists who believe that you cannot adequately teach a public policy course which features social problem areas such as homelessness, the AIDS epidemic, the drug epidemic, inadequate public education, or inadequate health services without "seeing" the problem first hand-visiting an emergency room in a local hospital or delivering meals to AIDS patients or to the homeless. There are some political scientists who believe that students cannot adequately learn about public administration without visiting a public agency or working in one as an intern. The purpose of this new APSA division is to promote and improve the quality and use of experience-based techniques in teaching political science.

Our panels will be the place to focus on such general themes as the place of experiential education in the political science curriculum and on such specific areas as establishing standards for grading, standards for awarding academic credit, and standards for supervising experiential learning. Papers which describe specific innovative courses or programs while exploring general themes are especially welcome.

45. Teaching and Learning in Political Science: Peter Zwick, Depart- ment of Political Science, California State University-San Marcos, San Marcos, CA 92026; 619-752-4089 (office); 619-752-4030 (fax); PETER_ZWICK@CSUSM.EDU (e-mail).

This division plans to conduct panels and roundtables on issues related to teaching and learning in political science at both the undergraduate and graduate levels. The goals of these sessions will be to share information and advance knowledge about political science instruction, and to encourage research on instruction as a legitimate scholarly activity.

This section recognizes that the primary responsibility of most political scientists is teaching, that virtually all academic political scientists teach on a regular basis, that teaching effectiveness can be enhanced through exposure to new ideas and techniques, and that there is a body of information about teaching and learning that can be shared. By opening the classroom experience to a wider audience, we hope to stimulate new initiatives that will make us more effective instructors and improve the quality of political science education.

As the theme of the 1994 Meeting is "Politics and Political Science in a Changing World," proposals featuring this theme are especially invited. Examples of topics that might fall under this rubric include: problems and innovations in teaching comparative politics, international relations, and modern political theory in the post-Soviet, post-Cold War era; revaluations of the Eurocentric political philosophy canon; incorporation of diversity issues in basic U.S. politics courses; or curricula developments around transitions to democracy.

General proposals for panels, papers, and roundtables on all aspects of political science instruction are also welcome. In order to stimulate thinking on the possibilities, I suggest the following list of possibilities, but it is not my intention to exclude any other ideas.

- Innovative course and curricula developments in political science, especially ones that incorporate multidisciplinary components, internships, service learning, and inter- 
national experiences.

- Critical analyses of text materials.

- Reports or studies on teaching methods and styles that have proven effective.

- The incorporation of the computer into the instructional environment.

- Innovations in teaching methods and course content that address multicultural or gender-based learning differences.

- Instruction that incorporates cooperative learning, including the case method, simulations, and other group work.

- Research on teaching effectiveness, including techniques of instructor evaluation, such as questionnaires, peer review, video recording, and other technologies.

- Research on student assessment and learning outcomes, including innovations in testing, research assignments, class projects, and senior experiences.

- Work on student recruitment and retention issues.

- New approaches to graduate education, especially curricula innovations.

- Programs to train graduate students to teach effectively.

Scholars teaching similar courses at different institutions are also invited to propose panels and roundtables that focus on instructional techniques and innovations in their particular field. For example, people teaching Constitutional Law might propose a panel on using the case approach in the undergraduate course. Likewise, international relations instructors who use the case method might wish to evaluate the effectiveness of various techniques. Those teaching political behavior might address issues of incorporating survey research experiences.

Faculty should also encourage students to propose panels and roundtables around their experiences, which might prove instructive to a broad cross-section on instructors. For example, students might evaluate "capstone" experiences, internships, independent studies, or case method classes.

Please feel free to propose additional ideas for panels and roundtables that you consider worthwhile. Our goal is to include and have an impact on all aspects of teaching and learning.

46. Public Opinion and Foreign Policy: Barbara Bardes, Ph.D., Dean, Raymond Walters College, University of Cincinnati, 9995 Planfield Road, Blue Ash, OH 45236; (513) 745-5600 (office) (513) 7455780 (fax)
The arrival of the post-Cold War era in international relations suggests that the publics of the United States and nations throughout the world will be facing new issues in foreign policy. As democratic reforms take hold in formerly authoritarian regimes, citizens will publicly debate and take positions on such issues as interventionism-economic, political and military; the role of the United Nations in world affairs; the creation of new ethnic or religious states; and issues involving international trade and competition.

Proposals are invited for papers and panels that will examine public opinion in the United States and from a comparative perspective on such issues as: multilateral action in the post-Cold War era; the role to be played by the United States, the European Community, and Japan in world affairs; and the justification of the use of force. Additionally, proposals are invited that look to the larger theoretical issues facing the field including the underlying dimensions of public opinion, the role played by information and emotion in opinion formation, and the tension between elite and mass opinion on foreign policy issues.

\section{WHAT IS SEPTEMBER 15, 1993? \\ It's the deadline for returning your updated form to APSA for the 1994-96 Directory of Members. The Directory is widely used as a resource for identifying speakers and area specialists as well as a reference for keeping in touch with colleagues.}

